Article

\title{
Cytotoxic Sesterterpenoids Isolated from the Marine Sponge Scalarispongia sp.
}

Yeon-Ju Lee ${ }^{1, *}$, Jeong-Woo Lee ${ }^{1}$, Dong-Geun Lee ${ }^{1}$, Hyi-Seung Lee ${ }^{1}$, Jong Soon Kang ${ }^{2}$ and Jieun Yun ${ }^{2}$

1 Marine Natural Product Chemistry Laboratory, Korea Institute of Ocean Science and Technology, Ansan 426-744, Korea; E-Mails: toyjwlee@gmail.com (J.-W.L.); trchapman@hanmail.net (D.-G.L.); hslee@kiost.ac (H.-S.L.)

2 Bio-Evaluation Center, Korea Research Institute of Bioscience and Biotechnology, Cheongwon 323-833, Korea; E-Mails: kanjon@kribb.re.kr(J.S.K.); jyun@kribb.re.kr (J.Y.)

* Author to whom correspondence should be addressed; E-Mail: yjlee@kiost.ac;

Tel.: +82-31-400-6171; Fax: +82-31-400-6170.

External Editor: Vladimír Křen

Received: 11 September 2014; in revised form: 21 October 2014 / Accepted: 23 October 2014 / Published: 4 November 2014

\begin{abstract}
Eight scalarane sesterterpenoids, including four new compounds, were isolated from the marine sponge Scalarispongia sp. The structures of the new compounds were elucidated by 2D-NMR and HRMS analyses. All of the isolated compounds, with the exception of 16-O-deacetyl-12,16-epi-scalarolbutanolide, showed significant in vitro cytotoxicity ( $\mathrm{GI}_{50}$ values down to $\left.5.2 \mu \mathrm{M}\right)$ against six human cancer cell lines.
\end{abstract}

Keywords: sponge; Scalarispongia; sesterterpenoid; scalarane; cytotoxicity

\section{Introduction}

Scalaranes are a group of sesterterpenoids with a characteristic carbon skeleton consisting of four cyclohexane rings joined together, and an optional five-membered heterocycle, which contains an oxygen or a nitrogen [1]. These compounds have been exclusively found from marine organisms such as sponges and nudibranchs, and never been isolated from terrestrial organisms, whereas a few examples of other types of sesterterpenoids isolated from plants, such as picracin [2,3], leucosceptrine [4,5], 
and salvimirzacolide [6], have been reported. It is believed that scalaranes play a key role in the chemical defense of marine invertebrates, as a large majority of these compounds exhibit cytotoxic and antifeedant activity. Thus, scalaranes have been considered as chemotaxonomic markers in marine invertebrates, and suggested as potential lead compounds for therapeutic agents.

Since the isolation of the first scalarane compound (scalarin, 1) from marine sponge Scalarispongia scalaris (previously known as Cacospongia scalaris) [7], extensive studies about the chemicals contained in marine sponges of Scalarispongia species have led to the discovery of various scalarane sesterterpenoids [8-13], and other terpenes such as furanosesterterpenes [14] and furanoditerpenes $[15,16]$.

Following our research on cytotoxic compounds obtained from Korean marine sponges, we herein report eight scalarne sesterterpenoids (1-8), including four new compounds (5-8), exhibiting promising level of cytotoxicity, which were isolated from Scalarispongia sp. collected off the coast of Dokdo, Republic of Korea.

\section{Results and Discussion}

\subsection{Isolation of Scalarane Sesterterpenoids from a Scalarispongia sp. Marine Sponge}

A freeze-dried Scalarispongia sp. sponge was macerated and extracted with methanol and dichloromethane; the combined extract was partitioned between $n$-butanol and water. The $n$-butanol fraction was then partitioned between $15 \%$ aqueous methanol and $n$-hexane, and the $15 \%$ aqueous methanol fraction was further partitioned between dichloromethane and 50\% aqueous methanol. The dichloromethane fraction was subjected to silica column chromatography, followed by HPLC using a silica column, to afford eight scalarane compounds (1-8).

\subsection{Structure Elucidation of Isolated Compounds}

A comparison of our NMR, LRMS and optical rotation data with those reported in previous literatures confirmed that compounds 1-4 are scalarin [7], 12-epi-12-O-acetylscalarolide [12], 12-O-acetyl-12,16-epi-scalarolbutenolide, and a 16-O-deacetylated derivative of 3 [17], respectively (Figure 1).

Figure 1. Structures of the isolated scalarane sesterterpenoids.
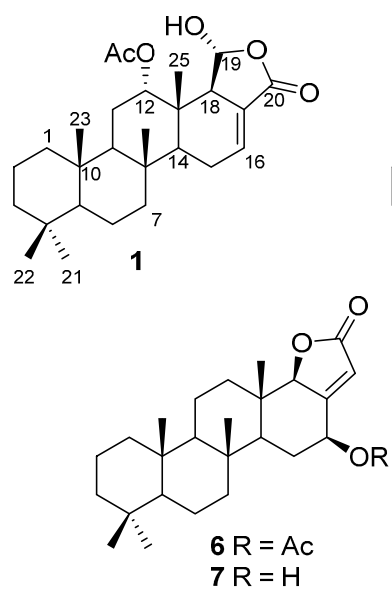
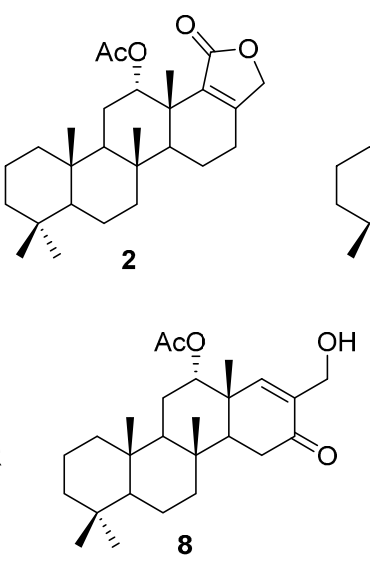

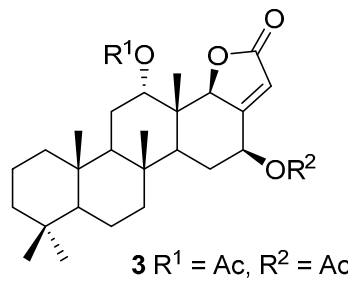

$4 R^{1}=A c, R^{2}=H$ $5 \mathrm{R}^{1}=\mathrm{H}, \mathrm{R}^{2}=\mathrm{H}$ 
Compounds 3-5 share the same carbon and oxygen framework with the only difference between these compounds being the degree of acetylation, as judged by ${ }^{1} \mathrm{H}-$ and ${ }^{13} \mathrm{C}-\mathrm{NMR}$ (Table 1) and HRMS data. In particular, compound 5 was identified as 16-O-deacetyl-12,16-epi-scalarolbutanolide (Figure 1), in agreement with the molecular formula of $\mathrm{C}_{25} \mathrm{H}_{38} \mathrm{O}_{4}$ obtained by HRMS analysis. While such a compound has never been reported, its C-12 epimer has been isolated from Hyrtios erecta [18]. The previously reported ${ }^{1} \mathrm{H}-\mathrm{NMR}$ data for the $\mathrm{C}-12$ epimer showed the proton being attached to C-12 $(\delta$ 3.67) with a trans-diaxial coupling $(J=11.2 \mathrm{~Hz})$ with an axial proton at $\mathrm{C}-11$; no such coupling was observed in the ${ }^{1} \mathrm{H}-\mathrm{NMR}$ spectra of $\mathbf{5}$. The stereochemistry of $\mathbf{5}$ was further confirmed by NOESY correlations (Figure 2).

Table 1. ${ }^{1} \mathrm{H}$ - and ${ }^{13} \mathrm{C}-\mathrm{NMR}$ data (500 and $125 \mathrm{MHz}$ ) for compounds $\mathbf{5}-\mathbf{7}$.

\begin{tabular}{|c|c|c|c|c|c|c|}
\hline \multirow{2}{*}{ Position } & \multicolumn{2}{|r|}{$5^{a}$} & \multicolumn{2}{|r|}{$6^{a}$} & \multicolumn{2}{|r|}{$7^{b}$} \\
\hline & סc, type ${ }^{c}$ & $\delta_{H}(J$ in Hz $)$ & $\delta c$, type $^{c}$ & $\delta_{H}(J$ in $\mathbf{H z})$ & $\delta c$, type $^{c}$ & $\delta_{H}(J$ in Hz $)$ \\
\hline \multirow{2}{*}{1} & \multirow{2}{*}{$39.2, \mathrm{CH}_{2}$} & $1.64, \mathrm{~m}$ & \multirow{2}{*}{$40.1, \mathrm{CH}_{2}$} & $1.68, \mathrm{~m}$ & \multirow{2}{*}{$40.2, \mathrm{CH}_{2}$} & $1.69, \mathrm{~m}$ \\
\hline & & $0.72, \mathrm{~m}$ & & 0.75 , ddd $(12.5,3.5,3.5)$ & & 0.78, ddd $(12.5,3.5,3.5)$ \\
\hline \multirow{2}{*}{2} & \multirow{2}{*}{$18.1, \mathrm{CH}_{2}$} & $1.42, \mathrm{~m}$ & \multirow{2}{*}{$18.8, \mathrm{CH}_{2}$} & $1.57, \mathrm{~m}$ & \multirow{2}{*}{$18.8, \mathrm{CH}_{2}$} & $1.55, \mathrm{~m}$ \\
\hline & & $1.22, \mathrm{~m}$ & & $1.40, \mathrm{~m}$ & & $1.40, \mathrm{~m}$ \\
\hline \multirow{2}{*}{3} & \multirow{2}{*}{$41.7, \mathrm{CH}_{2}$} & $1.20, \mathrm{~m}$ & \multirow{2}{*}{$42.2, \mathrm{CH}_{2}$} & $1.36, \mathrm{~m}$ & \multirow{2}{*}{$42.2, \mathrm{CH}_{2}$} & $1.35, \mathrm{~m}$ \\
\hline & & $0.98, \operatorname{ddd}(13.0,13.0,3.5)$ & & $0.95, \operatorname{ddd}(12.5,12.5,3.5)$ & & $1.10, \operatorname{ddd}(13.0,13.0,3.5)$ \\
\hline 4 & $32.8, \mathrm{C}$ & & $33.5, \mathrm{C}$ & & $33.5, \mathrm{C}$ & \\
\hline 5 & $56.1, \mathrm{CH}$ & 0.76, brd $(13.0)$ & $56.6, \mathrm{CH}$ & $0.82, \mathrm{~m}$ & $56.7, \mathrm{CH}$ & $0.78, \mathrm{~m}$ \\
\hline \multirow{2}{*}{6} & \multirow{2}{*}{$18.2, \mathrm{CH}_{2}$} & $1.40, \mathrm{~m}$ & \multirow{2}{*}{$18.4, \mathrm{CH}_{2}$} & $1.54, \mathrm{~m}$ & \multirow{2}{*}{$18.5, \mathrm{CH}_{2}$} & $1.54, \mathrm{~m}$ \\
\hline & & $1.30, \mathrm{~m}$ & & $1.29, \mathrm{~m}$ & & $1.40, \mathrm{~m}$ \\
\hline \multirow{2}{*}{7} & \multirow{2}{*}{ 41.7, $\mathrm{CH}_{2}$} & 1.66, ddd, $(12.5,3.0,3.0)$ & \multirow{2}{*}{$42.5, \mathrm{CH}_{2}$} & 1.77 , ddd $(13.0,4.0,3.0)$ & \multirow{2}{*}{$42.6, \mathrm{CH}_{2}$} & 1.81, ddd $(12.5,3.0,3.0)$ \\
\hline & & 0.92, ddd, $(12.5,12.5,3.0)$ & & 1.02, ddd $(13.0,13.0,4.0)$ & & $1.00,(12.5,12.5,3.0)$ \\
\hline 8 & $37.7, \mathrm{C}$ & & $38.2, \mathrm{C}$ & & $38.2, \mathrm{C}$ & \\
\hline 9 & $50.6, \mathrm{CH}$ & $1.32, \mathrm{~m}$ & $61.4, \mathrm{CH}$ & $0.87, \mathrm{~m}$ & $61.4, \mathrm{CH}$ & $0.81, \mathrm{~m}$ \\
\hline 10 & $36.6, \mathrm{C}$ & & $37.8, \mathrm{C}$ & & $37.8, \mathrm{C}$ & \\
\hline \multirow{2}{*}{11} & \multirow{2}{*}{$25.2, \mathrm{CH}_{2}$} & $1.54, \mathrm{~m}$ & \multirow{2}{*}{$17.2, \mathrm{CH}_{2}$} & $1.60, \mathrm{~m}$ & \multirow{2}{*}{$17.2, \mathrm{CH}_{2}$} & $1.59, \mathrm{~m}$ \\
\hline & & $1.28, \mathrm{~m}$ & & $1.38, \mathrm{~m}$ & & $1.33, \mathrm{~m}$ \\
\hline \multirow{2}{*}{12} & $702 \mathrm{CH}$ & $360 \mathrm{dd}(3030)$ & $405 \mathrm{CH}$ & $2.03, \mathrm{~m}$ & $407 \mathrm{CH}$ & 2.03, dd $(10.0,3.0)$ \\
\hline & $10.2, \mathrm{CII}_{1}$ & 3.00, du $(5.0,5.0)$ & $70.0,011$ & $1.33, \mathrm{~m}$ & TV. & $1.34, \mathrm{~m}$ \\
\hline 13 & $45.5, \mathrm{C}$ & & 41.6, C & & 41.6, C & \\
\hline 14 & $45.1, \mathrm{CH}$ & $1.19, \mathrm{~m}$ & $51.6, \mathrm{CH}$ & $1.09, \mathrm{~m}$ & $51.9, \mathrm{CH}$ & $1.05, \mathrm{~m}$ \\
\hline 15 & $306 \mathrm{CH}_{2}$ & 1.99, ddd $(12.5,8.0,2.0)$ & $28 \mathrm{O}_{\mathrm{CH}}$ & 2.19, ddd $(12.5,7.0,2.0)$ & $317 \mathrm{CH}_{2}$ & 2.17, ddd $(12.5,7.0,2.0)$ \\
\hline 10 & $30.0, \mathrm{C}_{112}$ & $1.33, \mathrm{~m}$ & $20.0, \mathrm{Cl1}_{2}$ & $1.47, \mathrm{~m}$ & $31.1, \mathrm{C} 112$ & $1.45, \mathrm{~m}$ \\
\hline 16 & $67.4, \mathrm{CH}$ & $4.26, \mathrm{dd}(10.0,8.0)$ & $69.8, \mathrm{CH}$ & $5.52, \operatorname{ddd}(11.5,7.0,2.0)$ & $69.0, \mathrm{CH}_{2}$ & 4.49, ddd $(9.3,7.0,2.0)$ \\
\hline 17 & $175.5, \mathrm{C}$ & & 167.0, C & & 171.7, C & \\
\hline 18 & $83.3, \mathrm{CH}$ & 5.06 , brs & $90.0, \mathrm{CH}$ & $4.33, \mathrm{~d}(2.0)$ & $90.1, \mathrm{C}$ & 4.29, brs \\
\hline 19 & 174.9, C & & $173.0, \mathrm{C}$ & & 173.5, C & \\
\hline 20 & $110.6, \mathrm{CH}$ & 5.73 , brs & $112.4, \mathrm{CH}$ & $5.76, \mathrm{dd}(2.0,2.0)$ & 111.9, $\mathrm{CH}_{2}$ & 5.90 , brs \\
\hline 21 & $32.9, \mathrm{CH}_{3}$ & $0.67, \mathrm{~s}$ & $33.5, \mathrm{CH}_{3}$ & $0.82, \mathrm{~s}$ & $33.4, \mathrm{CH}_{3}$ & $0.83, \mathrm{~s}$ \\
\hline 22 & $20.8, \mathrm{CH}_{3}$ & $0.65, \mathrm{~s}$ & $21.5, \mathrm{CH}_{3}$ & $0.78, \mathrm{~s}$ & $21.5, \mathrm{CH}_{3}$ & $0.79, \mathrm{~s}$ \\
\hline 23 & $16.0, \mathrm{CH}_{3}$ & $0.68, \mathrm{~s}$ & $16.5, \mathrm{CH}_{3}$ & $0.81, \mathrm{~s}$ & $16.5, \mathrm{CH}_{3}$ & $0.81, \mathrm{~s}$ \\
\hline 24 & 16.7, $\mathrm{CH}_{3}$ & $0.72, \mathrm{~s}$ & $17.7, \mathrm{CH}_{3}$ & $0.85, \mathrm{~s}$ & $17.7, \mathrm{CH}_{3}$ & $0.86, \mathrm{~s}$ \\
\hline
\end{tabular}


Table 1. Cont.

\begin{tabular}{|c|c|c|c|c|c|c|}
\hline \multirow{2}{*}{ Position } & \multicolumn{2}{|c|}{$5^{a}$} & \multicolumn{2}{|r|}{$6^{a}$} & \multicolumn{2}{|c|}{$7^{b}$} \\
\hline & $\delta_{C}$, type $^{c}$ & $\delta_{H}(J$ in $\mathrm{Hz})$ & $\delta_{C}$, type $^{c}$ & $\delta_{H}(J$ in $\mathbf{H z})$ & $\delta_{C}$, type $^{c}$ & $\delta_{H}(J$ in $\mathrm{Hz})$ \\
\hline 25 & $11.6, \mathrm{CH}_{3}$ & $0.51, \mathrm{~s}$ & $12.3, \mathrm{CH}_{3}$ & $0.70, \mathrm{~s}$ & $12.4, \mathrm{CH}_{3}$ & $0.69, \mathrm{~s}$ \\
\hline \multirow{2}{*}{ 16-OAc } & & & $170.0, \mathrm{C}$ & & & \\
\hline & & & $21.1, \mathrm{CH}_{3}$ & $2.16, \mathrm{~s}$ & & \\
\hline
\end{tabular}

${ }^{a}$ The ${ }^{1} \mathrm{H}$ - and ${ }^{13} \mathrm{C}$-NMR spectra are measured in $\mathrm{CDCl}_{3} / \mathrm{CD}_{3} \mathrm{OD}(3: 1) ;{ }^{b}$ The ${ }^{1} \mathrm{H}$ - and ${ }^{13} \mathrm{C}-\mathrm{NMR}$ spectra are measured in $\mathrm{CDCl}_{3} ;{ }^{c}$ Carbons correlating with the corresponding proton.

Compound 6 was deduced to have the molecular formula $\mathrm{C}_{27} \mathrm{H}_{40} \mathrm{O}_{4}$ based on the analysis of its HRFABMS. In ${ }^{1} \mathrm{H}$ - and ${ }^{13} \mathrm{C}-\mathrm{NMR}$ spectra of $\mathbf{6}$, unlike those of $\mathbf{3}$, no signals related to oxymethines were detected. Instead, methylene protons at $\delta 2.03$ and 1.33, which shows HSQC correlation with a carbon signal at $\delta 40.5$ and HMBC correlations with carbon signals at (C-25), 61.4 (C-9), and 51.6 (C-14), were observed (Table 1, Figure 3). These findings suggest that no substituent is present at C-12. The stereochemistry at C-16, where the remaining acetate group is attached, was confirmed by NOESY correlations (Figure 2).

Compound 7 was identified as a $16-O$-deacetylated derivative of 6 , as ${ }^{1} \mathrm{H}$ - and ${ }^{13} \mathrm{C}$-NMR data for 7 were similar to those obtained for $\mathbf{6}$, except for the signals of the acetyl group (Table 1). This is in agreement with the molecular formula $\mathrm{C}_{25} \mathrm{H}_{38} \mathrm{O}_{3}$ obtained by the analysis of HRFABMS. While several scalarin and scalaradial derivatives lacking the C-12 oxygen have been reported [19-22], isoscalarane derivatives such as $\mathbf{6}$ and 7 have never been reported previously.

Figure 2. Selected NOESY correlations for compounds 5-8.
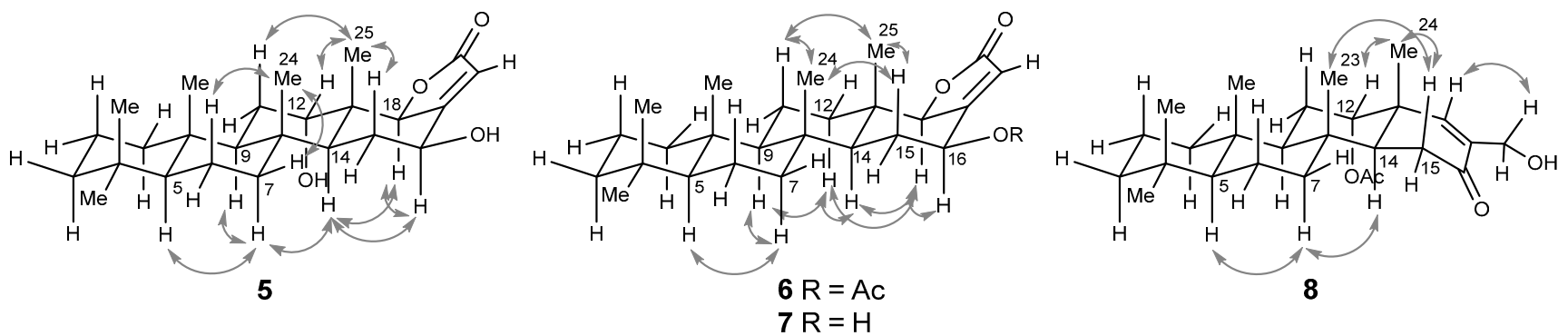

Figure 3. Selected COSY and HMBC correlations for compounds 5-8.

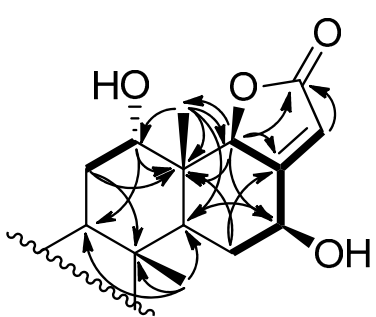

5

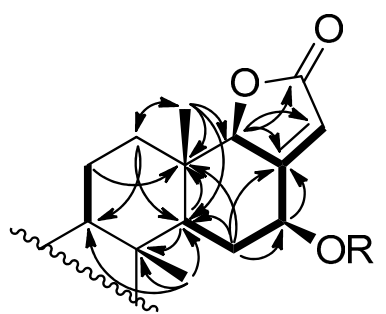

$6 \mathrm{R}=\mathrm{Ac}$ $7 \mathrm{R}=\mathrm{H}$

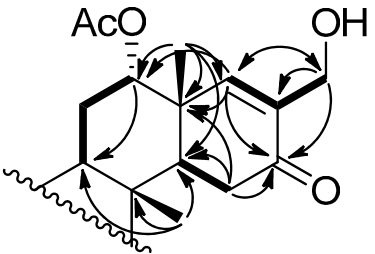

8

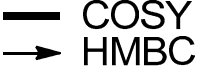

The molecular formula of compound $\mathbf{8}$, obtained by HRFABMS, was $\mathrm{C}_{26} \mathrm{H}_{40} \mathrm{O}_{4}$. The carbon signals at $\delta 202.0,135.4$, and 155.3 as well as a proton signal at $\delta 6.51$, which shows a HSQC correlation with 
a carbon signal at 155.3, suggested the presence of an $\alpha, \beta$-unsaturated ketone. A proton signal at $\delta 4.16$, which shows a HSQC correlation with a carbon signal at 62.1 and HMBC correlations with carbon signals of aforementioned unsaturated ketone, indicated that a hydroxymethyl group is attached to the $\alpha$-position of the carbonyl group. Based on these observations as well as the NOESY and HMBC correlations displayed in Figures 2 and 3, the structure of $\mathbf{8}$ could be elucidated unambiguously. Interestingly, most of tetracyclic scalaranes possess an oxo group at C-19 as well as a hydroxy or an acetate group at C-16 [1]. Despite the same oxidation state, the structure of 6 is diametrically opposed to other tetracyclic scalaranes.

The isolated compounds were tested for in vitro cytotoxicity against a panel of human cancer cell lines and the results are summarized in Table 2. All compounds, except for 5, showed potent inhibition of cancer cell growth. Compounds 5 showed no activity even at a concentration of $60 \mu \mathrm{M}$. This suggests that substitution at $\mathrm{C}-12$ is not a requirement for cytotoxicity; it is highly probable that the presence of a hydrogen bond donor at C-12 can significantly decrease the cytotoxicity of the scalarane derivatives.

Table 2. Growth inhibition of compounds 1-8 against a panel of human tumor cell lines ${ }^{a}$.

\begin{tabular}{ccccccc}
\hline \multirow{2}{*}{ Compound } & \multicolumn{7}{c}{ Cell Line $\left(\mathbf{G I}_{\mathbf{5 0}} \boldsymbol{\mu M M}\right)$} \\
\cline { 2 - 7 } $\boldsymbol{b}$ & $\mathbf{H C T - 1 5}$ & NCI-H23 & ACHN & MDA-MB-231 & NUGC-3 & PC-3 \\
\hline $\mathbf{1}$ & $7.38 \pm 0.07$ & $11.0 \pm 0.12$ & $6.01 \pm 0.02$ & $6.17 \pm 0.02$ & $7.25 \pm 0.04$ & $5.45 \pm 0.02$ \\
$\mathbf{2}$ & $6.52 \pm 0.05$ & $6.20 \pm 0.09$ & $5.43 \pm 0.01$ & $6.99 \pm 0.03$ & $6.13 \pm 0.03$ & $5.36 \pm 0.03$ \\
$\mathbf{3}$ & $7.75 \pm 0.08$ & $5.66 \pm 0.09$ & $6.17 \pm 0.04$ & $5.41 \pm 0.02$ & $5.66 \pm 0.03$ & $5.70 \pm 0.02$ \\
$\mathbf{4}$ & $8.17 \pm 0.06$ & $9.02 \pm 0.10$ & $6.99 \pm 0.02$ & $5.19 \pm 0.03$ & $8.98 \pm 0.04$ & $7.01 \pm 0.02$ \\
$\mathbf{5}$ & $>60.0$ & $>60.0$ & $>60.0$ & $>60.0$ & $>60.0$ & $>60.0$ \\
$\mathbf{6}$ & $9.11 \pm 0.09$ & $21.0 \pm 0.09$ & $6.69 \pm 0.04$ & $11.3 \pm 0.08$ & $21.0 \pm 0.02$ & $10.0 \pm 0.08$ \\
$\mathbf{7}$ & $11.6 \pm 0.09$ & $12.2 \pm 0.10$ & $7.22 \pm 0.07$ & $5.24 \pm 0.04$ & $12.2 \pm 0.04$ & $6.53 \pm 0.03$ \\
$\mathbf{8}$ & $7.85 \pm 0.05$ & $10.6 \pm 0.07$ & $6.60 \pm 0.03$ & $9.10 \pm 0.02$ & $10.2 \pm 0.09$ & $9.17 \pm 0.04$ \\
Doxorubicin & $1.53 \pm 0.02$ & $1.79 \pm 0.05$ & $1.85 \pm 0.01$ & $1.76 \pm 0.01$ & $1.50 \pm 0.02$ & $1.69 \pm 0.03$ \\
\hline
\end{tabular}

${ }^{a}$ HCT-15, colon cancer; NCI-H23, lung cancer; ACHN, renal cancer; MDA-MB-231, breast cancer; NUGC-3, stomach cancer; PC-3, prostate cancer; ${ }^{b} \mathrm{GI}_{50}$ values are the concentrations corresponding to $50 \%$ growth inhibition. Data are an average of at least two tests.

\section{Experimental Section}

\subsection{General Experimental Procedure}

The optical rotations were measured using a JASCO digital polarimeter using a $5 \mathrm{~cm}$ cell. IR spectra were recorded on a JASCO FT/IR-4100 (Jasco Inc., Easton, MD, USA). ${ }^{1} \mathrm{H}-\mathrm{NMR}$ spectra were recorded on a Varian Unity $500(500 \mathrm{MHz})$ spectrometer (Varian Inc., Palo Alto, CA, USA). Chemical shifts are reported in ppm from tetramethylsilane with the solvent resonance resulting from incomplete deuteration as the internal references $\left(\mathrm{CDCl}_{3}: \delta_{\mathrm{H}} 7.26 \mathrm{ppm}\right) .{ }^{13} \mathrm{C}-\mathrm{NMR}$ spectra were recorded on a Varian Unity $500(125 \mathrm{MHz})$ spectrometer with complete proton decoupling. Chemical shifts are reported in ppm from tetramethylsilane with the solvent as the internal reference $\left(\mathrm{CDCl}_{3}\right.$ : $\left.\delta_{C} 77.26 \mathrm{ppm}\right)$. HPLC was performed with YMC-Pack Silica columns using a Shodex RI-101 detector (Showa Denko K.K., Tokyo, Japan). 


\subsection{Biological Material}

The sponge Scalarispongia sp. was collected by hand using SCUBA at a $10 \mathrm{~m}$ depth offshore of Dokdo (island), Republic of Korea. The growth form of this specimen was a flattened or plate-like structure, up to $70 \mathrm{~mm}$ in size and $10 \mathrm{~mm}$ in thickness; the color in ethanol was black externally and light brown internally. The specimen's surface was uneven and unarmored, with microconules (1-2 mm) that are formed by protruding fibers scattered over the surface. The skeleton was of very wide regularity. Furthermore, it was reticulate in appearance (with prominent ladder-like shapes), consisting of primary $(150-250 \mu \mathrm{m})$ and secondary $(80-120 \mu \mathrm{m})$ clearly laminated and uncored fibers. The rectangular reticulum of the skeleton net had meshes with width of more than $2000 \mu \mathrm{m}$. A certain amount of fasciculation of fibers of both types was observed. The sponge was compressible and not difficult to break. This sponge has some resemblance to Scalarispongia (Porifera, Dictyoceratida, Thorectidae) in terms of very regular skeleton organization. The voucher specimens are deposited at the sponge collection of Korea Institute of Ocean Science and Technology (08DD06).

\subsection{Extraction and Isolation}

The collection $\left(1.0 \mathrm{~kg}\right.$, wet wt.) was immediately freeze-dried and kept at $-20{ }^{\circ} \mathrm{C}$ until the time of our investigation. The sponge was extracted using methanol $(1 \mathrm{~L} \times 2)$ and dicholoromethane $(1 \mathrm{~L} \times 1)$ at room temperature. The combined extract $(18.8 \mathrm{~g})$ was partitioned between $n$-butanol and water, and the organic layer $(6.4 \mathrm{~g})$ was further partitioned between $15 \%$ aqueous methanol and $n$-hexane. The aqueous methanol fraction ( $4.6 \mathrm{~g}$ ) partitioned again between dichloromethane and $50 \%$ aqueous methanol. Subsequently, dichloromethane fraction $(1.7 \mathrm{~g})$ was subjected to a silica gel column chromatography (230-400 mesh, Merck, Hunterdon County, NJ, USA) with ethyl acetate in $n$-hexane $(15 \%, 20 \%, 30 \%, 50 \%, 100 \%$ stepped gradient) and $10 \% \mathrm{MeOH}$ in dichloromethane. The fractions eluted with $20 \%, 30 \%, 50 \%$, and $100 \%$ ethyl acetate in $n$-hexane were purified by HPLC using silica column to afford $\mathbf{6}$ (4.8 mg), 3 (9.6 mg), 2 (12.4 mg), 8 (2.7 mg), 7 (1.4 mg), 1 (61.8 mg), 4 (58.4 mg), and $5(12.9 \mathrm{mg})$. Each known compound was identified by comparison of ${ }^{1} \mathrm{H}$ - and ${ }^{13} \mathrm{C}-\mathrm{NMR}$ spectra as well as HRMS data with those reported. Compound 5: pale yellow amorphous solid; $[\alpha]^{25} \mathrm{D} 33.6$ (c $0.5, \mathrm{CHCl}_{3} / \mathrm{CH}_{3} \mathrm{OH}(3: 1)$ ); UV $\lambda_{\max }(\log \varepsilon) 218$ (4.05) nm; IR (KBr) $v_{\max } 3396,2941,1746,1047$, $1047 \mathrm{~cm}^{-1} ;{ }^{1} \mathrm{H}-$ and ${ }^{13} \mathrm{C}-\mathrm{NMR}\left(\mathrm{CDCl}_{3} / \mathrm{CD}_{3} \mathrm{OD}(3: 1), 500\right.$ and $\left.125 \mathrm{MHz}\right)$, see Table 1 ; (+)-HRFABMS $m / z 403.2845[\mathrm{M}+\mathrm{H}]^{+}$(calcd for $\mathrm{C}_{25} \mathrm{H}_{39} \mathrm{O}_{4}, 403.2848$ ).

Compound 6: pale yellow amorphous solid; $[\alpha]^{25} \mathrm{D} 12.3$ ( $c$ 0.5, $\left.\mathrm{CHCl}_{3}\right)$; UV $\lambda_{\max }(\log \varepsilon) 229$ (2.56) nm; IR (KBr) $v_{\max } 2928,1755,1237,1067 \mathrm{~cm}^{-1}$; ${ }^{1} \mathrm{H}$ - and ${ }^{13} \mathrm{C}-\mathrm{NMR}\left(\mathrm{CDCl}_{3}, 500\right.$ and $\left.125 \mathrm{MHz}\right)$, see Table 1; (+)-HRFABMS $m / z 429.3008[\mathrm{M}+\mathrm{H}]^{+}$(calcd for $\mathrm{C}_{27} \mathrm{H}_{41} \mathrm{O}_{4}, 429.3005$ ).

Compound 7: pale yellow amorphous solid; $[\alpha]^{25} \mathrm{D} 9.2\left(c 0.5, \mathrm{CHCl}_{3}\right) ; \mathrm{UV} \lambda_{\max }(\log \varepsilon) 229$ (2.84) nm; IR (KBr) $v_{\max } 3400,2994,2361,1765,1241,1051 \mathrm{~cm}^{-1}$; ${ }^{1} \mathrm{H}-$ and ${ }^{13} \mathrm{C}-\mathrm{NMR}\left(\mathrm{CDCl}_{3}, 500\right.$ and $\left.125 \mathrm{MHz}\right)$, see Table 1; (+)-HRFABMS $m / z$ 387.2902 [M + H $]^{+}$(calcd for $\mathrm{C}_{25} \mathrm{H}_{39} \mathrm{O}_{3}, 387.2899$ ).

Compound 8: pale yellow amorphous solid; $[\alpha]^{25} \mathrm{D}-7.6\left(c\right.$ 0.5, $\left.\mathrm{CHCl}_{3}\right) ; \mathrm{UV}(\mathrm{MeOH}) \lambda \max (\log \varepsilon)$ 220 (4.04) nm; IR (KBr) $v_{\max }$ 2937, 2360, 1744, 1242, $1045 \mathrm{~cm}^{-1} ;{ }^{1} \mathrm{H}-\mathrm{NMR}\left(\mathrm{CDCl}_{3}, 500 \mathrm{MHz}\right)$ $\delta 6.51$ (1H, brs, H-18), 4.99 (1H, brs, H-12), 4.16 (2H, brs, H-19), 2.43 (1H, dd, J=18.0, $3.5 \mathrm{~Hz}, \mathrm{H}-15)$, $2.34(1 \mathrm{H}, \mathrm{dd}, J=18.0,14.0 \mathrm{~Hz}, \mathrm{H}-15), 2.09$ (1H, dd, $J=14.0,3.5 \mathrm{~Hz}, \mathrm{H}-14), 2.04$ (3H, s, 12-OAc), 
$1.80(1 \mathrm{H}, \mathrm{m}, \mathrm{H}-11), 1.71(1 \mathrm{H}, \mathrm{m}, \mathrm{H}-11), 1.68(1 \mathrm{H}, \mathrm{m}, \mathrm{H}-7), 1.58(1 \mathrm{H}, \mathrm{m}, \mathrm{H}-1), 1.56(1 \mathrm{H}, \mathrm{m}, \mathrm{H}-2)$, $1.55(1 \mathrm{H}, \mathrm{m}, \mathrm{H}-6), 1.38(1 \mathrm{H}, \mathrm{m}, \mathrm{H}-6), 1.36(1 \mathrm{H}, \mathrm{m}, \mathrm{H}-2), 1.26(1 \mathrm{H}, \mathrm{d}, J=13.0,4.0 \mathrm{~Hz}, \mathrm{H}-9)$, 1.24 (1H, m, H-3), 1.11 (3H, s, H-24), 1.08 (1H, m, H-3), 0.99 (1H, ddd, $J=14.5,12.5,3.0, \mathrm{H}-7)$, $0.91(3 \mathrm{H}, \mathrm{s}, \mathrm{H}-23), 0.87$ (1H, m, H-5), 0.79 (3H, s, H-21), $0.80(3 \mathrm{H}, \mathrm{s}, \mathrm{H}-22), 0.83$ (3H, s, H-20), $0.60(1 \mathrm{H}, \mathrm{m}, \mathrm{H}-1) ;{ }^{13} \mathrm{C}-\mathrm{NMR}\left(\mathrm{CDCl}_{3}, 125 \mathrm{MHz}\right) \delta 202.0$ (C-16), 170.8 (12-OAc), 155.3 (C-18), 135.4 (C-17), 76.3 (C-12), 62.1 (C-19), 56.8 (C-5), 52.8 (C-9), 49.4 (C-14), 42.1 (C-3), 41.0 (C-13), 40.7 (C-7), 39.8 (C-1), 37.4 (C-8), 37.1 (C-10), 34.3 (C-15), 33.5 (C-4), 33.5 (C-20), 22.3 (C-11), 21.6 (C-21), 21.5 (12-OAc), 19.6 (C-24), 18.6 (C-6), 18.1 (C-2), 16.6 (C-23), 16.2 (C-22); (+)-HRFABMS $m / z 417.3008[\mathrm{M}+\mathrm{H}]^{+}$(calcd for $\mathrm{C}_{26} \mathrm{H}_{41} \mathrm{O}_{4}, 417.3005$ ).

\subsection{Cytotoxicity Assay}

The growth inhibition assays against human cancer cell lines, in particular, HCT-15 (colon), NCI-H23 (lung), ACHN (renal), MDA-MB0231 (breast), NUGC (stomach) and PC-3 (prostate), were carried out according to a published protocol [23]. In brief, cancer cells were added to a 96-well plate containing control (doxorubicin) or test compounds. After being incubated for $48 \mathrm{~h}$, cultures were fixed with $50 \%$ trichloroacetic acid $(50 \mu \mathrm{g} / \mathrm{mL})$ and stained with $0.4 \%$ sulforhodamine B in $1 \%$ acetic acid. Unbound dye was removed by washing with $1 \%$ acetic acid and protein-bound dye was extracted with $10 \mathrm{mM}$ Tris base ( $\mathrm{pH}$ 10.5) for determination of optical density. The absorbance at $540 \mathrm{~nm}$ was determined using a VersaMax microplate reader (Molecular Devices, LLC., Sunnyvale, CA, USA).

\section{Conclusions}

In summary, eight scalarane sesterterpenoids (1-8), including four new compounds (5-8), were isolated from the Korean marine sponge of Scalarispongia species. Among the new compounds, compounds $\mathbf{6}$ and 7 are the first isoscalarane derivatives lacking the C-12 oxygen, and compound $\mathbf{8}$ is diametrically opposed to other reported tetracyclic scalaranes, which have an oxo group at C-19 and a hydroxy or an acetate group at C-16. The isolated compounds showed cytotoxicity against a panel of human cancer cell lines in all tested cases, with the exception of compound $\mathbf{5}$, which showed no cytotoxicity against the cancer cell lines considered in this study. The results presented in this contribution may provide new insight into the mode of cytotoxicity of scalarane sesterterpenoids.

\section{Supplementary Materials}

Supplementary materials can be found at http://www.mdpi.com/1422-0067/15/11/20045/s1.

\section{Acknowledgments}

This work was supported by a grant of the Korea Institute of Ocean Science and Technology and the Ministry of Oceans and Fisheries of Korea. We thank Young Hwan Kim (Korea Basic Science Institute, Daegu, Republic of Korea) for providing HRFABMS data and Vladimir. B. Krasokhin (Pacific Institute of Bioorganic Chemistry, Far-Eastern Branch of the Russian Academy of Science, Vladivostok, Russia) for identifying the sponge. 


\section{Author Contributions}

Collection of the Scalarispongia sp., isolation and purification of the secondary metabolites, and structure elucidation of scalarane sesterterpenoids were carried out by Yeon-Ju Lee, Jeong-Woo Lee, Dong-Geun Lee, Hyi-Seung Lee. Evaluation of the cytotoxicity of the isolated compounds was carried out by Jong Soon Kang and Jieun Yun. Yeon-Ju Lee wrote the manuscript and the manuscript was finalized through contributions from all authors.

\section{Conflicts of Interest}

The authors declare no conflict of interest.

\section{References}

1. González, M.A. Scalarane sesterterpenoids. Curr. Bioact. Compd. 2010, 6, 178-206.

2. Laurie, W.A.; McHale, D.; Sheridan, J.B. A cucurbitacin glycoside from Picrorhiza kurrooa. Phytochemistry 1985, 24, 2659-2661.

3. Smit, H.F.; van den Berg, A.J.J.; Kroes, B.H.; Beukelman, C.J.; Quarles van Ufford, H.C.; van Dijk, H.; Labadie, R.P. Inhibition of T-lymphocyte proliferation by cucurbitacins from Picrorhiza scrophulariaeflora. J. Nat. Prod. 2000, 63, 1300-1302.

4. Choudhary, M.I.; Ranjit, R.; Atta ur, R.; Hussain, S.; Devkota, K.P.; Shrestha, T.M.; Parvez, M. Novel sesterterpenes from Leucosceptrum canum of Nepalese origin. Org. Lett. 2004, 6, 4139-4142.

5. Choudhary, M.I.; Ranjit, R.; Atta ur, R.; Shrestha, T.M.; Yasin, A.; Parvez, M. LeucosceptrineA novel sesterterpene with prolylendopeptidase inhibitory activity from Leucosceptrum canum. J. Org. Chem. 2004, 69, 2906-2909.

6. Moghaddam, F.M.; Amiri, R.; Alam, M.; Hossain, M.B.; van der Helm, D. Structure and absolute stereochemistry of salvimirzacolide, a new sesterterpene from Salvia mirzayanii. J. Nat. Prod. 1998, 61, 279-281.

7. Fattorusso, E.; Magno, S.; Santacroce, C.; Sica, D. Scalarin, a new pentacyclic C-25 terpenoid from the sponge Cacospongia scalaris. Tetrahedron 1972, 28, 5993-5997.

8. Tsoukatou, M.; Siapi, H.; Vagias, C.; Roussis, V. New sesterterpene metabolites from the Mediterranean sponge Cacospongia scalaris. J. Nat. Prod. 2003, 66, 444-446.

9. Cafieri, F.; de Napoli, L.; Iengo, A.; Santacroce, C. Minor pyrroloterpenoids from the marine sponge Cacospongia mollior. Experientia 1979, 35, 157-158.

10. De Rosa, S.; Crispino, A.; de Giulio, A.; Iodice, C.; Tommonaro, G.; Zavodnik, N. A new dimethylscalarane derivative from the sponge Cacospongia scalaris. Tetrahedron 1998, 54, 6185-6190.

11. Yasuda, F.; Tada, H. Desacetylscalaradial, a cytotoxic metabolite from the sponge Cacospongia scalaris. Experientia 1981, 37, 110-111.

12. Rueda, A.; Zubia, E.; Ortega, M.J.; Carballo, J.L.; Salva, J. New cytotoxic metabolites from the sponge Cacospongia scalaris. J. Org. Chem. 1997, 62, 1481-1485.

13. Cimino, G.; Cafieri, A.F.; de Napoli, L.; Fattorusso, E. ${ }^{13}$ C-NMR spectrum and absolute stereochemistry of furoscalarol. Tetrahedron Lett. 1978, 19, 2041-2044. 
14. Fusetani, N.; Kato, Y.; Matsunaga, S.; Hashimoto, K. Bioactive marine metabolites V. Two new furanosesterterpenes, inhibitors of cell division of the fertilized starfish eggs, from the marine sponge Cacospongia scalaris. Tetrahedron Lett. 1984, 25, 4941-4942.

15. Tanaka, J.; Marriott, G.; Higa, T.; Higa, T. Cacofurans A and B, new furanoditerpenes from a marine sponge. J. Nat. Prod. 2001, 64, 1468-1470.

16. Guella, G.; Amade, P.; Pietra, F. Cacospongione A, cacospongienone A, and cacospongienone B, new C21 difuran terpenoids from the marine sponge Cacospongia scalaris SCHMIDT of the Cote d'Azur. Helv. Chim. Acta 1986, 69, 726-733.

17. Lu, Q.; Faulkner, D.J. Two new sesterterpenoids and a new 9,11-secosterol from Spongia matamata. J. Nat. Prod. 1997, 60, 195-198.

18. Ryu, G.; Matsunaga, S.; Fusetani, N. Three new cytotoxic sesterterpenes from the marine sponge Hyrtios cf. erectus. J. Nat. Prod. 1996, 59, 515-517.

19. Rho, J.-R.; Lee, H.-S.; Shin, H.J.; Ahn, J.-W.; Kim, J.-Y.; Sim, C.J.; Shin, J. New sesterterpenes from the sponge Smenospongia sp. J. Nat. Prod. 2004, 67, 1748-1751.

20. Song, J.; Jeong, W.; Wang, N.; Lee, H.-S.; Sim, C.J.; Oh, K.-B.; Shin, J. Scalarane sesterterpenes from the sponge Smenospongia sp. J. Nat. Prod. 2008, 71, 1866-1871.

21. Hahn, D.; Won, D.H.; Mun, B.; Kim, H.; Han, C.; Wang, W.; Chun, T.; Park, S.; Yoon, D.; Choi, H.; et al. Cytotoxic scalarane sesterterpenes from a Korean marine sponge Psammocinia sp. Bioorg. Med. Chem. Lett. 2013, 23, 2336-2339.

22. Tokue, T.; Miura, S.; Kato, H.; Hirota, H.; Ohta, T.; Tsukamoto, S. Neurotrophic sesterterpenes isolated from a marine sponge, Spongia sp. Heterocycles 2006, 69, 521-526.

23. Skehan, P.; Storeng, R.; Scudiero, D.; Monks, A.; McMahon, J.; Vistica, D.; Warren, J.T.; Bokesch, H.; Kenney, S.; Boyd, M.R. New colorimetric cytotoxicity assay for anticancer-drug screening. J. Natl. Cancer Inst. 1990, 82, 1107-1112.

(C) 2014 by the authors; licensee MDPI, Basel, Switzerland. This article is an open access article distributed under the terms and conditions of the Creative Commons Attribution license (http://creativecommons.org/licenses/by/4.0/). 